\title{
The Cultural Expression of Campus Landscape Design in Higher Vocational Colleges under the Background of School - Enterprise Cooperation
}

\author{
Yanping Bai \\ Jiangsu Vocational Institute of Commerce, Nanjing, Jiangsu, 211168
}

Keywords: School-Enterprise Cooperation; Vocational Colleges; Campus Culture; Campus Landscape Design

\begin{abstract}
The construction of campus culture in higher vocational colleges is an important way to enhance the connotation of vocational colleges. It can better promote the students' all-round development. Under the background of school-enterprise cooperation, we should pay attention to the construction of campus culture by using campus landscape design in higher vocational colleges The In the actual campus culture construction process, we need to pay attention to fully follow the principle of complementarity, pragmatism and education, so as to effectively highlight the professional application of vocational colleges, industry orientation and career selection, and so on , And better promote the healthy and sustainable development of higher vocational colleges in China. Therefore, under the background of school-enterprise cooperation, this paper analyzes and studies the landscape approach of campus culture construction in higher vocational colleges.
\end{abstract}

\section{Introduction}

Higher vocational education is an important part of higher education in our country. Nowadays, in the process of deepening reform of teaching education in our country, higher vocational colleges need to pay attention to continuously strengthen the construction of campus culture, give full play to the construction of culture, so as to better enhance Students' cognitive level, better build awareness of the community, and promote the development of the whole regional economy. Now the model of school-enterprise cooperation is the emerging mode of higher vocational education, which can be better to narrow the connection between enterprises and schools and cooperation, and constantly promote the common progress and development of both sides, it is clear that vocational colleges because of their own the traditional vocational teaching methods can not effectively adapt to the development of society, need to focus on standing in the context of school-enterprise cooperation in the campus landscape design, campus culture penetration, to achieve the campus landscape Education function.

\section{The Importance of Campus Landscape in Cultural Education}

With the rapid development of our society in recent years, there is a higher and more objective requirement for the construction of campus culture in higher vocational colleges. First of all, the sustainable and healthy development of society is the need for colleges and universities to effectively provide talent, science and technology and advanced ideological theory, and this content and the construction of high school campus culture has an inseparable link. Second, because our country is still in the early stages of the development of socialism, which also requires vocational colleges to effectively provide appropriate application-oriented, technical high-end talent [1]. At present, the status quo of campus culture construction in higher vocational colleges in our country can be found that the construction of campus culture in higher vocational colleges still can not meet the requirements of social development effectively. Only by effectively improving the spiritual culture, material culture and institutional culture of vocational colleges and landscape culture 
construction, can effectively improve the level of running higher vocational schools. The cultural connotation of campus landscape design in higher vocational colleges can create a good learning atmosphere, constantly improve the students' own literacy, realizes the common growth and development of teachers and students, so the cultural connotation of campus landscape design in higher vocational colleges Show is the inevitable requirement of our country's social development.

Higher vocational colleges are an important base for cultivating talents. Higher education has the important function of promoting people's development and social development. At the same time, under the new situation of school-enterprise cooperation, the cultural expression of campus landscape design is also the construction Harmonious campus and society an important guarantee [2]. Only in the establishment of a harmonious campus culture, can we build a harmonious society, the school landscape space is an important space for students in school activities, but also an important platform for school school demonstrations, college landscape is always accompanied by the development of the school. School-enterprise cooperation is an important way for the reform and development of school reform. Therefore, in the construction of campus landscape, it is necessary to pay attention to highlight the harmonious campus culture, so as to promote the construction of harmonious campus. In the process of campus landscape design, pay attention to the harmonious development of humanistic landscape and natural landscape, pay attention to the organic development of social development and ecological environment, in the actual landscape design process, to fully realize the landscape effect and ecological function is the need for co-ordination Take care of. Only through this way can we effectively demonstrate the characteristics and professional level of higher vocational colleges, and better promote the common development of teachers and students, to ensure that vocational colleges in the context of school-enterprise cooperation, healthy and sustainable development.

Higher vocational education itself is to cultivate practical and technical professionals, in the context of the current school-enterprise cooperation, you can cultivate both a solid professional theoretical knowledge, but also can cultivate a strong operational skills, In line with the needs of business people [3]. With the current era of industrialization and large-scale production, the actual mode of production has undergone major changes, which shows that vocational colleges need to focus on landscape design in the context of school-enterprise cooperation to explore the full recognition of vocational colleges Their own shortcomings, attention to continuously improve the students' humanities. Whether it is social or business talent for humanities and professional ethics have a high demand, so in the campus landscape design process, we need to focus on continuously improve the continuous upgrading of vocational college students' humanities, better Promoting the Socialization of Students in Higher Vocational Colleges.

\section{The Principles of Campus Landscape Design in Higher Vocational Colleges}

In the landscape design of higher vocational colleges into the enterprise elements, it is the innovation of the cultural construction of higher vocational colleges. At the same time, because of the differences between the corporate culture and the campus culture itself, the two are in the pursuit of the goal, the core of culture, the degree of competition and the role of radiation are essentially different [4]. Therefore, it is necessary in the actual vocational school campus landscape design process, we must adhere to the inheritance and development of cultural principles, to avoid the full set of campus landscape design into the corporate elements and culture, need to pay attention to follow the scientific. The cultural culture of landscape design in higher vocational colleges is the embodiment of the history and culture of the institutions where the institutions are located, and the culture of the institutions themselves, such as the typical campus buildings, the characteristics of the disciplines and so on, all through the development of institutions And gradually formed, which can fully reflect the strength of vocational colleges themselves.

With the current integration of various disciplines and development, architecture, art aesthetics, landscape ecology and environmental art and other disciplines, can be the concept of sustainable development into the campus landscape design process [5]. Campus landscape design is not only simple for teachers and students to create a clear and comfortable environment, not only to meet the 
teachers and students of teaching and life use, more importantly, the need for landscape design in the full embodiment of people and nature Aspects of the sustainable development of the ecological. The concept of sustainable development is also the most important concept in the corporate culture. Therefore, the natural ecological environment can be used as an important part of the self-circulation in the actual landscape design process, such as water resources, wind power and solar energy. At the same time also pay attention to the landscape design process, fully embodies the characteristics of today's industrial production, and actively use modern advanced high-tech, as a material carrier, through the campus landscape design to build a healthy and good ecological environment, in the concept of sustainable development effectively instilled in the students.

China's various vocational colleges between the characteristics and nature of the subject has a certain difference, which led to the cultural connotation between each school has a certain difference, each school in the actual development process, will gradually form Its own cultural traditions, historical humanities, landscape style and so on. In the process of landscape construction of various colleges and universities in China, we will focus on the historical origins, cultural resources and so on of mining institutions, so as to effectively show the unique culture of the campus [6]. In the context of the current school-enterprise culture cooperation, higher vocational colleges should not only pay attention to fully tap their own historical origins, but also pay attention to fully reflect the core culture and enterprise characteristics, such as the campus design and business Content related to the cultural wall. In this way so that students can better understand the development of enterprises and future prospects, so as to better highlight the school's own academic characteristics, and constantly enhance the school's learning atmosphere.

\section{The Enterprise Culture in the Enterprise Elements in the Campus Landscape Design Implantation Approach}

In order to integrate into the enterprise elements of the enterprise culture, it is necessary to focus on analyzing the core cultural elements in the enterprise, corporates culture elements [7]. In the actual campus landscape design process, enterprises and schools should be aware that some of the core elements of the enterprise can not be effectively injected into higher vocational colleges, such as some corporate strategic management, organizational job design concept, the characteristics of salary incentive system And the concept of leadership culture and so on, although it can become part of the teaching of professional courses in vocational colleges, but it is difficult to implement in the construction of characteristic culture in higher vocational colleges. Therefore, in the process of campus landscape design in higher vocational colleges, it is possible to inject cultural elements such as career aspirations, professional ethics, humanistic quality requirements and entrepreneurial cultural concepts into the campus landscape design, which can effectively activate and enrich The Construction of Characteristic Culture of Higher Vocational Colleges in China.

The cooperation between schools and enterprises is an important way to cultivate professional and technical talents in higher vocational colleges and enterprises. It is also an important way to promote the development and innovation of higher vocational colleges. School-enterprise cooperation is an effective way to improve vocational colleges Competitiveness, reflecting the characteristics of vocational colleges, colleges and universities to solve the employment problem of an important way [8]. Therefore, in the process of campus landscape design, we should pay close attention to the process of combining the professional academic system and the process of carrying out campus culture activities, so as to ensure the scientific implantation of corporate culture elements. General enterprise elements into the content can be divided into theoretical learning links and practice links, you can inject some of the enterprises in the slogan, such as Haier business service concept is "sincere to forever", which fully reflects the Haier business for Customer concerns, corporate social responsibility to actively fulfill the corporate culture elements. Vocational colleges themselves should pay attention to digging the cultural elements in the enterprise, and actively in the campus landscape design into such cultural elements, and constantly create a good professional atmosphere, effectively highlight the characteristics of higher vocational colleges, through this way to achieve The Common Development of Higher Vocational Colleges and 
Enterprises in China.

Vocational colleges and colleges and universities have a certain difference between China's higher vocational colleges itself is to emphasize the higher and "vocational education" both, although the campus cultural landscape although there will be some commonality, but to the effective Enhance their own competitiveness, and gradually form a common vision. It is necessary to pay attention to the effective combination of the characteristics of corporate culture, as well as vocational school conditions, personnel training objectives and school philosophy, pay attention to the full emphasis on the characteristics of vocational education, and constantly strengthen the professional characteristics of their own services industry The introduction of corporate culture campus, to ensure that students can feel the corporate culture at any time breath. For example, you can open up a unique space in the school, the enterprise's laboratories, production lines and workshop models and other enterprises, social production environment into the campus culture, tourism management, landscape architecture, decoration, environmental art and other professional, In the design of some with less than the characteristics of the landscape model [9]. Through this way, we can effectively improve the educational atmosphere and characteristics of higher vocational colleges in our country, and provide good teaching materials for students' training and learning. School-enterprise cooperation is to achieve a win-win way of higher vocational colleges and enterprises, so we should focus on the gradual formation of a common vision to ensure that the school environment for the school's teaching services, but also to ensure that enterprises can effectively expand the school's education Way to continuously expand the students' learning space, effectively open up new learning model, and better promote the healthy development of Chinese enterprises and higher vocational colleges.

\section{Conclusion}

In short, the current school-enterprise cooperation for the development of China's enterprises and vocational colleges opened up a new road, vocational colleges in the context of school-enterprise cooperation and we should pay attention to the campus landscape design, the full combination of campus landscape planning To promote the scientific development of campus landscape design in higher vocational colleges. At the same time pay attention to the full combination of landscape design and cultural expression of the relationship, it effectively reflects the campus of the professional, regional characteristics, academic characteristics, and constantly enhances the campus landscape culture, and better promotes the development of campus and business.

\section{Acknowledgements}

Jiangsu Province 2017 University Philosophy and Social Science Research Fund Project Title: Cultural Expression of Campus Landscape Design in Higher Vocational Colleges under the Background of School-Enterprise Cooperation ID: 2017SJB0629

\section{References}

[1] Liu Hua. Discussion on the Countermeasure of Moral Education in Higher Vocational Colleges under the Background of School-enterprise Cooperation [J]. Industry and Technology Forum, 2014, 16: 170-171.

[2] He Lihui. School-enterprise cooperation under the background of higher vocational colleges cultural construction [J]. Liaoning Higher Vocational Journal, 2014,12: 11-12 +80.

[3] Shu Li. School-enterprise cooperation under the background of higher vocational colleges scientific research management innovation [J] .Guangxi Journal of Police College, 2013,03: 78-80.

[4] Huang Ruiyuan, Yang Nan, Zheng Xiong. School-enterprise cooperation under the background of vocational sports culture and corporate culture docking research [J]. Sports, 2013, 10: 85-86. 
[5] Chen Qiang, Hu Jianxiong. Contradiction between school-enterprise cooperation and campus culture docking in vocational colleges - Construction of campus culture conducive to professional quality development [J]. Liaoning Economy, 2013, 11: 88-91.

[6] Liu Fanrong, Ma Ke. The influence of corporate culture and campus culture on the cooperation between universities and enterprises in vocational colleges - Taking Jiangxi Tourism Business School and Yum Group as an example [J]. Vocational Education Forum, 2013, 35: 46-48.

[7] Tang Xiaocui, Liu Xuanqi. On the school-enterprise cooperation to build vocational school campus culture thinking [J]. Journal of Guangxi Normal University, 2013, 06: 180-182.

[8] He Liping.Study on the Teaching Reform of Ideological and Political Theory Course in Higher Vocational Colleges under the Background of School - enterprise Cooperation - Taking Liaoning Modern Service Vocational and Technical College as an Example [J]. Journal of Changchun Institute of Education, 2012,03: 136-137.

[9] Zhang Shubin. School-enterprise cooperation under the perspective of vocational colleges and universities campus culture [J]. Commercial culture (the first half), 2011, 05: 53. 